Research, part of a Special Feature on Resilience Through Multi-scalar Collaboration

\title{
The US Fire Learning Network: Springing a Rigidity Trap through Multiscalar Collaborative Networks
}

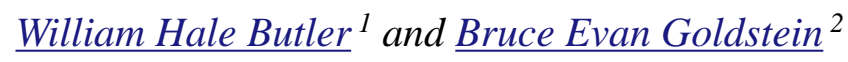

\begin{abstract}
Wildland fire management in the United States is caught in a rigidity trap, an inability to apply novelty and innovation in the midst of crisis. Despite wide recognition that public agencies should engage in ecological fire restoration, fire suppression still dominates planning and management, and restoration has failed to gain traction. The U.S. Fire Learning Network (FLN), a multiscalar collaborative endeavor established in 2002 by federal land management agencies and The Nature Conservancy, offers the potential to overcome barriers that inhibit restoration planning and management. By circulating people, planning products, and information among landscape- and regional-scale collaboratives, this network has facilitated the development and dissemination of innovative approaches to ecological fire restoration. Through experimentation and innovation generated in the network, the FLN has fostered change by influencing fire and land management plans as well as federal policy. We suggest that multiscalar collaborative planning networks such as the FLN can facilitate overcoming the rigidity traps that prevent resource management agencies from responding to complex cross-scalar problems.
\end{abstract}

Key Words: collaborative planning; ecologicalfire restoration; fire management; FLN; learning networks; multiscalar networks; resilience; rigidity trap; U.S. Fire Learning Network

\section{INTRODUCTION}

Wildland fire management in the United States is caught in what Gunderson and Holling (2002) call a "rigidity trap" of pathological resistance to novelty and innovation. Nearly forty years ago, fire scientists embraced a dynamic perspective of natural fire regimes and fire agencies called an end to the war against fire on the wildlands, abandoning a commitment to wildfire suppression that had dominated U.S. fire management policy and practice (Pyne 2004). Fire scientists and managers recognized that fire-adapted ecosystems had been harmed by overzealous suppression, that growing fuel loads were exacerbating wildfire problems, and that restoring natural fire regimes should be a priority in fire management policy and practice. Nonetheless, despite changes in agency rhetoric and fire management policy over the last several decades, fire suppression continues to be reinforced through incentive structures, agency budgets, and professional practice (Arno and Allison-Bunnell 2002). Instead of making ecological restoration the core of fire management practice, land management agencies are devoting ever greater resources to suppressing fires that continue to grow in extent and intensity.

Following record-setting wildland fire seasons, The Nature Conservancy (TNC), the U.S. Department of Agriculture (USDA) Forest Service, and the land management agencies of the U.S. Department of Interior (DOI) in 2002 created the U.S. Fire Learning Network (FLN). The FLN enables participants to collaborate across organizational and administrative boundaries to develop landscapescale ecological restoration plans for fire-adapted ecosystems. Since its inception, the FLN has included participants from 650 organizations and has developed collaborative ecological restoration plans in more than 150 landscapes linked through 14 regional networks. Regional networks enable leading landscape-level participants to work together to enhance their capacities to collaboratively plan and manage at the landscape scale.

The FLN shapes, transmits, and reinforces the practice of landscape-scale ecological fire 
restoration planning and management. In this multiscalar collaborative network, participants seek not only to overcome the barriers that prevent restoration of fire-adapted ecosystems but also to address some of the core challenges that perpetuate fire management's rigidity trap. As landscape collaboratives and regional networks generate creative approaches to engage in ecological fire restoration, the network facilitates diffusion of innovation to other landscapes and regions as well as to fire professionals and policy makers outside the network. In this paper, we focus on how the FLN enhances opportunities to engage in ecological fire restoration by informing public land management plans and federal fire policy. The FLN has not transformed fire management, but by influencing critical plans and policies, it has fostered the potential to spring the rigidity trap. We suggest that collaborative networks like the FLN may be particularly suited to promoting cross-scalar socialecological resilience.

\section{METHODS}

Since 2005, we have been studying the design, function, and accomplishments of the FLN. Using a case study approach (Stake 1995, Yin 2003), we conducted more than 140 interviews with network leaders, participants, and high-level staff in participating organizations. We attended and recorded audio at over a dozen regional and national workshops and leadership meetings. We also reviewed hundreds of documents, including fire restoration plans, geographic information system (GIS) maps and models, interorganizational agreements, meeting agendas, meeting summaries, network newsletters, listserv communications, and media reports. Furthermore, we have used qualitative analytical methods (aided by NVivo analysis software [QSR International]) to develop codes and categories for characterizing how the FLN fosters innovation across multiple scales and then disseminates innovation beyond network boundaries (Yin 2003, Charmaz 2006).

\section{RESILIENCE AND RIGIDITY TRAPS}

Resilient social-ecological systems respond to disturbances by maintaining structural and functional complexity within a variety of potential system configurations (Folke et al. 2002, Walker et al. 2004). Although resilience suggests stability, social-ecological resilience thinkers suggest that resilience maintains a system within any of its possible stable states, rather than seeking the highest degree of system efficiency at a single equilibrium point (Gunderson and Holling 2002). Thus, socialecological resilience implies an adaptive system and is associated with self-organization, a capacity to integrate learning and adaptation, and an ability to restore system function and structure in the face of perturbation or change (Berkes et al. 2002).

Stable and durable institutions can be an obstacle to broader social-ecological resilience, maintaining themselves despite shocks or perturbations that might otherwise catalyze adaptive change (Allison and Hobbs 2004, Carpenter and Brock 2008). Without innovation and adaptation, a system can get caught in a "rigidity trap" (Gunderson and Holling 2002), unable to break free from the conservation stage that maintains the status quo. Rigidity traps were first described in natural resource management bureaucracies that perpetuated themselves at the expense of the productivity and vitality of the ecosystems that they managed (Gunderson and Holling 2002). Resource managers tend to reduce natural variation because dependent industries require predictability and desire maximization in productivity of certain resources. This behavior enables the bureaucracy to persist, but consequent negative ecological and social feedbacks increase the likelihood of catastrophic events and unanticipated dramatic change (Holling et al. 2002).

This process can be self-correcting when extreme events such as wildfires or hurricanes foster change in long-established rules and practices (Schusler et al. 2003). However, extreme events may also engender other feedback processes that work to maintain the status quo, such as the financial and/ or political support that accompanies continued crisis management. Things may remain the same even when resource managers recognize that things would improve if they approached their work differently (Repetto and Allen 2006). Change can be threatening: it can disrupt familiar procedures and ways of knowing, require new training, and bring about uncertainties associated with reorganization (Goldstein 2007). 


\section{THE POTENTIAL OF COLLABORATION TO SPRING THE TRAP}

The FLN relies on multistakeholder collaborative processes to enhance innovation by providing a multitude of testing grounds for alternative relationships and work practices (Goldstein and Butler 2009). Place-based multistakeholder collaboration is particularly effective not only at resolving disputes and generating consensus-based agreements but also at fostering learning, change, and identity formation (Gray 1989, Healey 1997, Innes and Booher 1999). However, a bounded and place-based multistakeholder process may be insufficient to bring about structural change across spatial, temporal, and organizational scales.

Management of complex systems requires crossscale linkages at both horizontal and vertical levels among institutions and ecological systems (Berkes and Folke 1998, Ostrom et al. 2002, Berkes 2004). Rather than relying on collaboration in isolated units, multiscalar approaches provide a collaborative structure to link multiple units at multiple scales. Extending beyond their origins in place-based multistakeholder dispute resolution, collaborative planning scholars have begun to examine multiscalar collaborative endeavors and seek ways to develop a framework for cross-scalar collaborative governance (Margerum and Whitall 2004, Innes et al. 2007, Weber and Hayward 2008). Participants in a collaborative network can develop common assumptions and expectations that enable them to act autonomously in the service of a common purpose (Goldstein and Butler 2009). This early work suggests that collaborative planning networks may provide coherent responses to crossscalar and emergent environmental challenges, fostering the potential to "set in motion cascades of changes in attitudes, behaviors, actions, practices, and institutions" (Innes et al. 2007).

Collaborative networks, then, may be able to influence the reorganization of social-ecological systems at multiple scales (Cash et al. 2006, Olsson et al. 2007, Pahl-Wostl et al. 2007). In this paper, we examine the potential of a multiscalar collaborative network to undertake experiments that can inspire transformative change. In particular, we explore the extent to which the FLN fosters a transition from fire suppression to ecological restoration by springing a particularly venerable, durable, and costly rigidity trap.

\section{FIRE MANAGEMENT'S RIGIDITY TRAP}

Wildland fire management in the United States emerged with the establishment of public land management agencies around the turn of the $20^{\text {th }}$ century. The fledgling agencies were invested in a utilitarian conservationist ethic that focused on maintaining resource production (Hays 1999). In this context, fire was considered an enemy and therefore had to be eliminated from the landscape (Langston 1995, Pyne 2004). The USDA Forest Service (USFS) took the lead and created a national system of fire prevention and suppression (Pyne et al. 1996).

Since the 1970s, fire management has been in a frustrated transition and a social-ecological crisis has been growing. With the emergence of ecological sciences attuned to disturbance dynamics (Worster 1994), fire began to be seen not simply as a destructive force but also as a necessary force of change and renewal. Total suppression became anathema to responsible ecological management. Many of the forests that had long been "protected" through fire suppression not only were amassing excessive fuel loads that stoked large conflagrations but also were suffering from increased disease and pest outbreaks. Amidst declining ecological functionality and uncharacteristically large wildland fires, federal land management agencies became overstretched and struggled to respond to an everworsening crisis (Pyne 2004).

In the late 1990s and early 2000s, conflagrations of record frequency and intensity led the U.S. Congress and the public to scrutinize the previously insular world of fire management (Davis 2006, National Interagency Fire Center 2009). Wildland fire policy came to embrace multiple goals, including ecosystem restoration, fuels reduction, and community protection (Steelman and Burke 2007). Both the National Fire Plan (USFS and US DOI 2001) and the Healthy Forests Restoration Act (2003) aimed to curb the cycle of declining ecological health and ballooning fire control budgets.

While these new policies highlighted the importance of ecologically informed fire management, they left unchanged the organizational incentives, budget priorities, and professional practices of agency land managers (Kennedy and Quigley 1998, Arno and Allison-Bunnell 2002, USDA Office of Inspector General 2006). Fire 
suppression continued to dominate, with 98 percent of all forest fires suppressed regardless of ignition source (USDA Office of Inspector General 2006). Despite near-universal recognition of the need for change and a continued crisis in fire management, the system still resists reorganization. As Pyne (2004) concludes, "the issue is not that we have failed to cross the divide, but that we have so little to show for having breached it decades ago."

U.S. fire management's rigidity trap is maintained by a variety of factors, including the continued maintenance of plans and policies that reinforce the longstanding focus on fire suppression, the increasing convergence of urban development on the edges of wildlands, and the deeply embedded professional practices and certification processes of fire managers as firefighters. The growing crisis at the wildland-urban interface (WUI) in the last decade of the $20^{\text {th }}$ century reinvigorated the central mission of fire suppression in federal agencies (Pyne 2004). As plans and policies emphasized protection of human life and property above other factors, fire managers were presented with few options at the WUI other than to extinguish all fires. An audit in 2006 revealed that from 1998 to 2005, less than two percent of the nearly 80,000 naturally ignited fires on Forest Service land were allowed to burn (USDA Office of Inspector General 2006). One contributing factor was the lack of plans that guided management toward ecological restoration objectives, while another was the concern among fire managers that the flames might encroach on human settlements nearby. Meanwhile, fire managers still continue to be trained in wildland fire education programs that only marginally have begun to introduce firefighting professionals to new knowledge in fire ecology and behavior for the purpose of ecological restoration (Kobziar et al. 2009).

Exacerbating this situation, federal policies that call for ecological fire restoration have not been accompanied by sufficient support for restoration action on the ground. Fire restoration funding has declined in recent decades, whereas spending on wildland fire suppression has greatly increased (USFS 2009). For the last two decades, the USFS has had to reallocate funds to support recordbreaking suppression costs at the expense of other line items in the overall management budget, including funds for ecological restoration (Dombeck et al. 2004, Backus 2007, Daly 2007, Steelman and Burke 2007).

\section{THE FIRE LEARNING NETWORK}

In 2001, TNC, the USFS, and the DOI signed a cooperative agreement to create the Fire Learning Network. The next year, federal agencies allotted nearly $\$ 1$ million per year to the agreement, and TNC hired network coordinators and support staff. Initially, 25 landscape collaboratives across the United States took part in a two-year planning process to generate ecological restoration plans on landscapes ranging from 100,000 to 11 million acres. By 2003, the demand to participate in the network had grown so much that the FLN staff had grouped landscapes into regional networks (Fire Learning Network 2003). At the end of 2009, 61 landscapes were linked through eight regional networks to develop collaborative landscape-scale ecological restoration plans for fire-adapted ecosystems (Fig. 1).

FLN organizers envisioned that "by fostering innovation and transferring lessons learned" among participants and beyond, the network would "accelerate the implementation of ecologically based and culturally acceptable fuels reduction and fire regime restoration strategies at ecologically meaningful scales ..." (TNC 2010). By linking collaborative planning processes across the nation, the network would enhance the ability of fire managers to develop scientifically sound and socially acceptable ecological fire restoration plans. At the same time, cross-scalar connections would facilitate the identification and dissemination of innovations throughout the network.

The FLN links multiple place-based collaboratives together into a larger network at regional and national scales. In Fig. 2, we depict the network system as a series of interconnected spheres of activity. Each level of the network performs certain tasks appropriate to the scale and purpose of network action at that level. At the landscape level, diverse stakeholders representing various organizations and professions involved in fire management collaboratively develop ecological fire restoration plans as well as modeling or mapping tools to incorporate into those plans. These stakeholders experiment with new ideas generated within their collaborative group or through interactions at regional and national levels, field-test new practices, and share resources across organizational boundaries to enable landscape-scale management. 
Fig. 1. Map of the active U.S. FLN landscapes and regions, December 2009. [Courtesy of the Director of the FLN.]

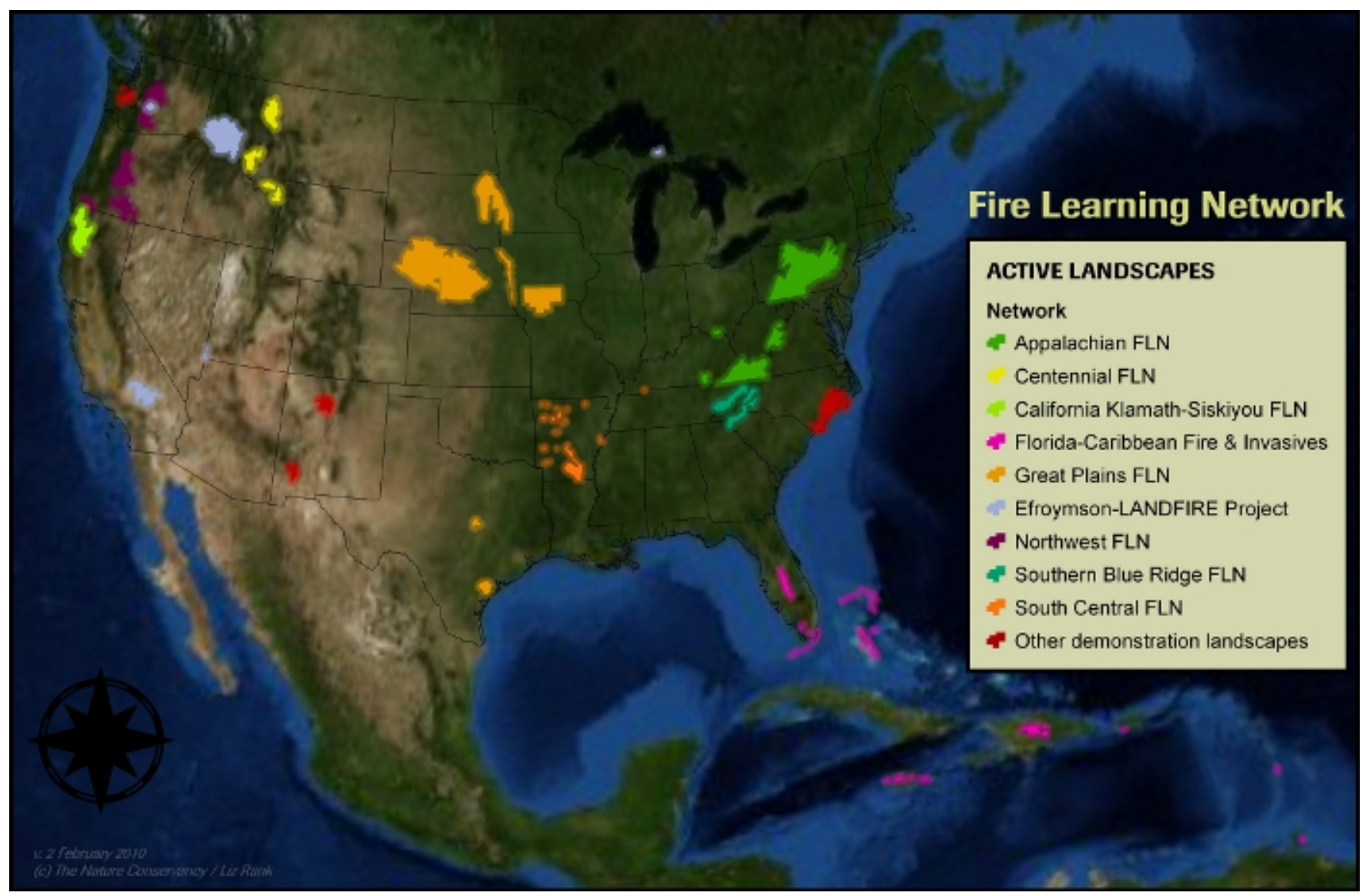

Regional networks consist of five to thirteen landscapes. Each network brings together leading participants from landscape collaboratives to develop collaboration skills and to prepare restoration plans for fire-adapted ecosystems. Participants compare plans, discuss how their landscape team produced these plans, and exchange ideas on how to overcome barriers to plan implementation. Regional workshops help participants develop new planning techniques and products as well as reflect on how to improve their collaborative practice, develop new partnerships, and build consensus in their respective landscapes.

The national network provides funding and professional staff to enable landscape and regional level meetings, guide planning processes, and ensure cross-scalar communication and learning. The national staff gather success stories and lessons learned at each level of the network, and they coordinate communication to share information across the network and beyond through newsletters, project guides, briefing documents, websites, and presentations. The national network provides participants with opportunities to learn what it means to be successful in the FLN and to take part in that nationwide communication.

These activities do not occur in isolation at each level, because participants, information, and materials circulate through all levels of the network. Landscape representatives attend regional workshops to present landscape-level work and obtain feedback as they collectively analyze their respective 
Fig. 2. The cross-scalar circulation of FLN participants, planning products, and information throughout the network. This circulation is accomplished through network workshops, web-based and print communications, and the movement of participants between different levels of the network. The doubleheaded bold arrow indicates that the boundaries between the levels of the network are permeable, with information, planning products, and participants flowing freely across them.

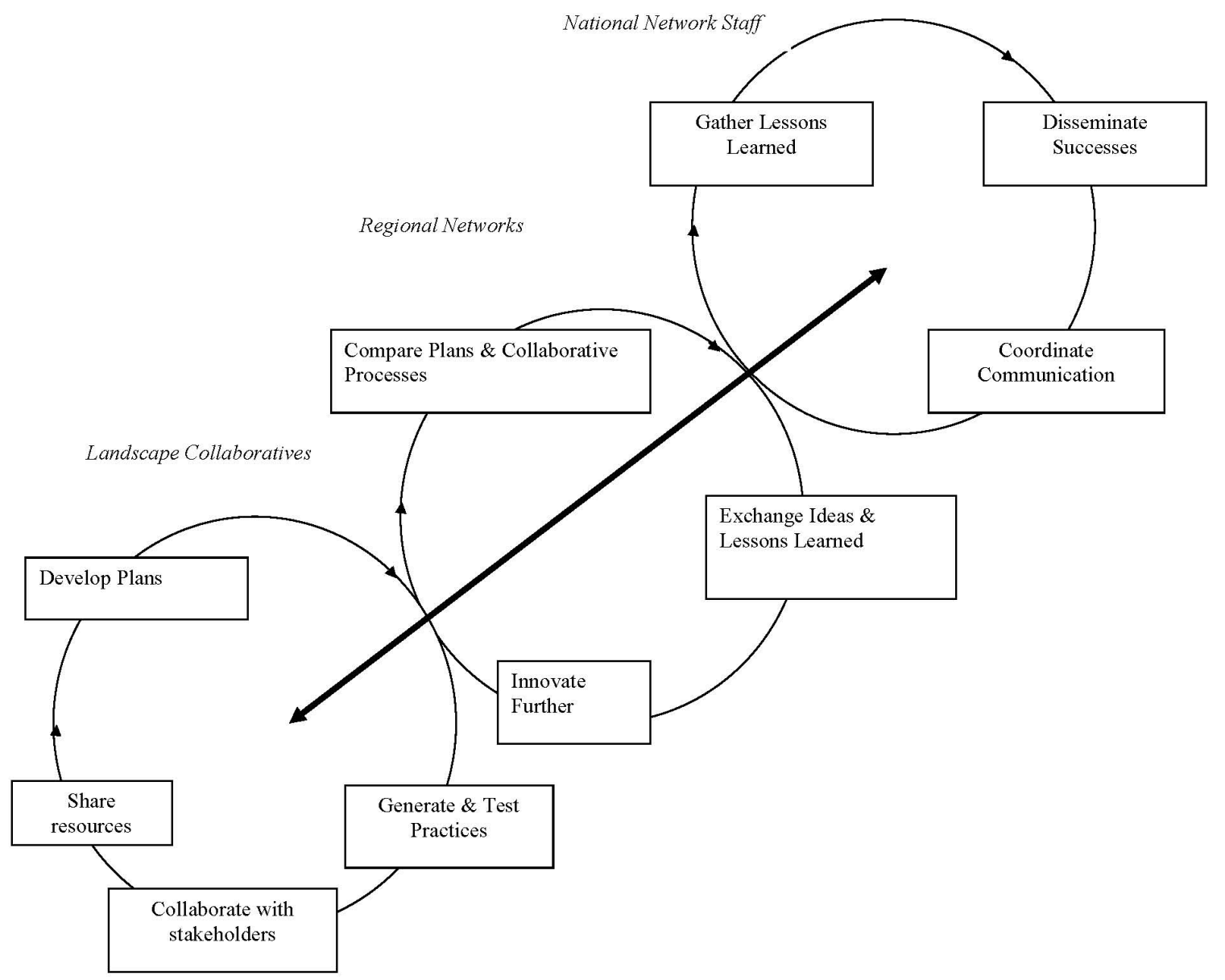

planning products and generate new ideas. Regional leaders attend landscape-level gatherings to facilitate collaborative planning processes or disseminate innovative practices emerging from other landscapes and regional forums. Regional and landscape leaders gather in national meetings to provide input into the design and activities of the overall network, to highlight and share practices with each other, and to develop creative responses to common challenges across the nation. National leaders present information at regional meetings and counsel regional leaders as they shape agendas and guide planning processes. This circulation of people is accompanied by a circulation of planning products, modeling tools, and representations that focus network action and serve as knowledge translation mechanisms across network levels. Websites, databases, video conferences, and other 
remote means of communication serve as repositories of network products and as communication forums to highlight specific innovations. The boundaries between levels within the network are permeable: participants, planning products, and information all flow freely.

Cross-scalar circulation of people, products, and information in the network has prompted the generation and dissemination of innovative fire planning and management techniques. An illustration of these multiscalar dynamics can be seen in the experience of the Applegate Partnership, an organization promoting ecosystem health and diversity in the watershed of the Applegate River in Oregon, USA. This group became part of the Northwest FLN (NWFLN) in 2004 because they wished to expand their longstanding collaborative efforts to include the restoration of fire-adapted ecosystems. In one of their planning exercises, the Applegate partners used a protocol to identify social and ecological indicators for adaptive management by conducting workshops across their landscape in southern Oregon. At the November 2007 NWFLN regional workshop, Applegate landscape leaders presented this protocol and their results and obtained feedback from participants at the regional level. During a breakout session, participants from other landscape collaboratives began to establish frameworks to conduct this approach within their own landscapes. Following the regional workshop, the Applegate group refined their process and engaged in a values mapping exercise to "build consensus for restoration in complex plant and human communities" (FLN Networker, \#38, September 9, 2009 [e-newsletter]) and to identify spatially explicit locations for restoration project implementation on federal lands.

Building on the Applegate approach and adapting the process to their particular social-ecological systems, other NWFLN participants conducted similar values mapping and treatment prioritization processes on four national forests within landscapes participating in the network. These landscape collaboratives have made progress in setting goals for ecological restoration and identifying priority areas for treatments. Their restoration goals and prioritizations have influenced agency and private lands management plans as well as guided federal funding requests. These efforts have yielded results, as the NWFLN's Deschutes National Forest project and Tapash Sustainable Forest Collaborative were among the ten landscapes that received federal funding for ecological fire restoration implementation in 2010 from the newly created Collaborative Forest Landscape Restoration Program (CFLRP).

National FLN leaders took note of the applicability of the values mapping and treatment prioritization exercises and subsequently featured the process used by the Applegate group in a network-wide Web-based seminar. Federal agency leaders have also taken note and have requested that the Region 6 Regional Forester learn about the process, assess its applicability to other social and political contexts, and present the findings in Washington, D.C. As this example demonstrates, the FLN uses a variety of means, including workshops, web- and print-based communications, field excursions, leadership meetings, and collaborative planning exercises at all levels of the network to promote the cross-scalar circulation of innovative planning and management approaches as well as the application of these approaches in varied social-ecological contexts.

\section{RESULTS AND ANALYSIS}

In this analysis, we focus on how the FLN has the potential to address fire management's rigidity trap. First, we examine how the network has helped to integrate ecological fire restoration perspectives and practices into land management plans. We describe how these plans have guided land managers toward the implementation of ecological fire restoration on the ground and suggest how, in some cases, restoration implementation has dramatically increased following plan revisions. Second, we trace how the network influences fire management policy by circulating success stories and identifying barriers to ecological restoration. We also provide an example of how the network promoted a federal initiative to fund ecological fire restoration.

\section{Ecologically oriented fire planning and management}

FLN informs a variety of management plans that guide fire management activities on the ground. The initiators of the network designed planning exercises to ensure compatibility with agency plans. As one of the original network coordinators recalls, "we designed [the planning exercises] so the products would roll into one of their NEPA 
[National Environmental Policy Act] documents or one of their management plans seamlessly" (D. Zollner, June 12, 2006, personal communication). Many of the FLN regions and landscapes specifically identify the importance of influencing agency management plans in their proposals and workshops. Evidence that FLN planning products have been incorporated into agency planning processes came from a 2007 FLN participant survey, in which $45 \%$ of respondents noted that the FLN had informed prescribed burn plans on their landscapes and $37 \%$ reported influence of FLN materials on fire management planning. FLN products also informed a variety of land management plans at the federal, state, and local levels, including USFS Land and Resource Management Plan revisions for $16 \%$ of respondents and Community Wildfire Protection Plans for $12 \%$ of respondents.

As an example, the Ozark-Saint Francis National Forest Land and Resource Management Plan (LRMP) revisions were finalized in September 2005 (USFS 2005). Two ranger districts were participating in the South Central FLN (SCFLN) regional network at the time of the revisions process: the Bayou Ranger District and the Pleasant Hill Ranger District. According to one participant, "The whole restoration component of the forest plan at the forest level came right out of the FLN" (D. Zollner, June 14, 2006, personal communication).

In the previous version of the plan (written in 1987), all management areas were designated as timber management areas: the old plan focused on how to identify the appropriate mix of species and ages of trees to maximize the output of wood fiber. In contrast, the 2005 revisions borrow heavily from the landscape-scale ecological restoration approach modeled by the FLN. The LRMP incorporates ecological fire restoration in the ten-year vision statement and draws directly from the planning products developed for the Bayou and Pleasant Hill districts, which established historic reference conditions for each of these ecological system types. Progress is being made toward restoring open, firemaintained, dry oak and pine woodland ecosystems based on the ecological potential and capability of the land. Natural processes are mimicked to create landscape patterns that resemble historic reference conditions (USFS 2005). The LRMP establishes restoration management areas for both pine and oak woodland systems. For these management areas, "Progress is being made toward restoring open, fire- maintained, dry oak and pine woodland ecosystems based on the ecological potential and capability of the land. Natural processes are mimicked to create landscape patterns that resemble historic reference conditions" (USFS 2005). Timber management is not excluded from these areas, but all timber activities must cohere with the overarching ecological restoration objective, which is a realignment of priorities from the 1987 plan.

Moreover, the plan establishes a prescribed burn objective informed by the FLN, stating that annual burning should cover an average of 120,000 acres across all community types in the forest and that one-third should be burned during the growing season (USFS 2005). The extent of the burning area and the importance of growing season burning were described in the FLN products produced by the Bayou and Pleasant Hill teams and vetted in SCFLN regional workshops.

FLN participants and planning products played essential roles in integrating ecological fire restoration in the plan revisions. The ecologist from the Bayou District credits the FLN process for guiding landscape participants to develop the scientific justification for restoration of ecological systems, which led to the adoption of restoration areas in the management plan (J. Andre, June 12, 2006, personal communication). Meanwhile, FLN partners provided input to the planning process, further reinforcing the need to incorporate a restoration component in the land management plan (D. Zollner, June 14, 2006, personal communication).

Since the plan revisions were applied, the ecological restoration programs on the forest have grown considerably. Land managers were able to increase prescribed burning from 2000 acres per year to 20,000 acres per year over their first two years of participation in the FLN. The prescribed burning program expanded to cover 76,000 acres per year in the Ozark National Forest by 2007. By the end of 2008, every ranger district in the Ozark SaintFrancis National Forest had an ecological restoration project enrolled in the FLN (M. Anderson, December 8, 2008, personal communication). Meanwhile, the Bayou Ranger District ecologist reported that by the end of 2008, the original FLN project areas totaling 60,000 acres had been restored to an oak-woodland ecosystem, meeting the plan objective more rapidly than originally projected (J. Andre, March 13, 2009, personal communication). 
In this case, the FLN enabled the integration of landscape-scale ecological fire restoration principles and practices into land management plans by means of the cross-scalar circulation of practitioners and planning products throughout the network and beyond. The Bayou and Pleasant Hill landscapes served as sites of experimentation. Guided and supported by the regional and national levels of FLN, landscape teams conducted experimental restoration treatments, developed and implemented monitoring protocols for adaptive management, built a scientific justification for restoration action, and collaborated with partners to come up with an ecologically sound and socially acceptable approach to restoring fire-adapted ecosystems. This approach from the ground up fundamentally changed the focus of the LRMP from timber production, in which the role of fire was largely ignored, to ecological restoration, in which fire became central to the analysis and implementation of the plan's vision and strategies. Since the plan was revised, new landscape collaboratives have enlisted in the SCFLN, capitalizing on the capacities generated through the network to enable implementation of ecological restoration projects in other locations throughout the forest. These efforts reinforce the focus of land management professionals on ecologically oriented fire management practice.

\section{Inspiring policy to enable ecological fire restoration}

From the inception of the network, FLN participants have recognized the need to shift state and national fire management policy (L. Decker, March 18, 2009, personal communication). Over time, FLN landscape collaboratives have identified and communicated on-the-ground frustrations and success stories to back up arguments for policy change. In this way, the network has inspired and informed changes to fire management policies to enable landscape-scale ecological fire restoration.

One example is the Forest Landscape Restoration Act (2008). TNC government relations staff along with FLN participants had identified that ecological fire restoration was being incorporated into management plans but was not sufficiently funded to effectively implement projects on the ground. TNC staff worked with key lawmakers in the US Congress to develop legislation to help overcome this problem. Using FLN landscapes as models,
TNC staff periodically contacted network leaders to make sure policy language would be applicable to the varied social and ecological contexts of FLN landscapes. As one staffer notes, "We were going back to the FLN, to this set of landscapes that I felt had enough experience to be able to answer the question 'If we wrote the bill this way, would it work for you?" (L. McCarthy, June 11, 2009, personal communication). The authors of the bill used the input from network leaders to write it in a way that promoted the FLN approach to collaborative landscape-scale ecological restoration.

This legislation aimed to "encourage the collaborative, science-based ecosystem restoration of priority forest landscapes" and would have established the Collaborative Forest Landscape Restoration Program (CFRLP), providing up to $\$ 40$ million a year over ten years to support landscapescale ecological restoration projects. FLN participants, including conservation scientists and fire managers from both public agencies and nonprofit organizations, were among those who testified before the U.S. Congress about the importance of restoration at this scale. The Forest Landscape Restoration Act of 2008 did not come to a vote as a separate Act, but the text of this bill was subsequently included in the Omnibus Public Land Management Act (2009) and was signed into law on March 30, 2009. With passage of this omnibus Act, Congress launched a program to invest up to $\$ 400$ million to support collaborative landscapescale ecological restoration projects.

This Act established new U.S. federal-level support and has the potential to greatly increase the federal investment in ecological restoration projects (Steelman and Burke 2007). Multiscalar circulation of FLN people, plans, and media informed the focus and content of this policy change and provided stories and insights to assist policy advocates as they formulated the legislation. State and federal policy changes inspired by FLN participants, products, and information serve to refocus fire management toward a greater emphasis on ecological fire restoration. Reciprocally, these changes to federal policy have further enabled collaborative landscape-scale ecological fire restoration practices on the ground. On August 13, 2010, USDA Secretary Vilsack announced the first ten landscape projects to be funded under the CFLRP, including three projects on FLN landscapes. 


\section{SPRINGING A RIGIDITY TRAP}

As the challenges of social-ecological resilience and sustainability extend beyond the capacities and boundaries of existing institutions, new governance arrangements are needed that operate at multiple organizational and spatial scales (Berkes 2002, Young 2002). Existing institutions in natural resource management are often inhibited by what Gunderson and Holling (2002) label a "pathology of regional resource and ecosystem management" in which agencies become increasingly rigid and excessively myopic. This pathology "can lead to a crisis triggered by unexpected external events, sometimes followed by a reformation of policy" (Gunderson and Holling 2002). Fire management is no exception. After four decades of recognizing the problem, fire management agencies have been unable to address it. The catastrophic wildfires, extensive property damage, and exploding costs of containment at the end to the 20th century generated top-down directives such as the National Fire Plan and the Healthy Forests Restoration Act (2003). These directives called for a greater focus on ecological restoration of fire-adapted ecosystems. However, restoration efforts have largely been tentative and peripheral, and conventional means to address the problem have fallen short.

The FLN is an example of a multiscalar collaborative planning network that has the potential to overcome these challenges. In this paper, we have described how the FLN has influenced two changes in fire management. First, FLN landscape collaboratives and regional networks facilitated integration of ecological restoration objectives and practices into public agency fire and land management planning. Second, the FLN generated and disseminated stories that highlighted successes or identified obstacles to fire restoration. These stories have been used to develop and gather support for policy change. In this network, change was inspired from the bottom up: practitioners generated creative responses to complex management challenges on the ground and then influenced responses at higher organizational levels.

Although the incremental shifts we have described here were insufficient to spring the rigidity trap, they do show how change can occur. The FLN facilitates cross-scalar circulation of ecological fire restoration perspectives and practices, enabling change at multiple scales simultaneously. The network fosters innovation among practitioners, influences plans and policies, and then builds on new guidance from those plans and policies to enable further experimentation and innovation. In this way, a multiscalar collaborative network like the FLN may be the means to engender greater social-ecological resilience by overcoming the rigidity traps that characterize many natural resource management bureaucracies.

Responses to this article can be read online at: http://www.ecologyandsociety.org/voll5/iss3/art21/ responses/

\section{Acknowledgments:}

This article is based on research supported by grants from the U.S.D.A. Forest Service Northern Research Station and The Nature Conservancy.

\section{LITERATURE CITED}

Allison, H. E., and R. J. Hobbs. 2004. Resilience, adaptive capacity, and the "lock-in trap" of the Western Australian agricultural region. Ecology and Society 9(1): 3. [online] URL: http://www.ecol ogyandsociety.org/vol9/iss1/art3/.

Arno, S. F., and S. Allison-Bunnell. 2002. Flames in our forest: disaster or renewal? Island Press, Washington, D.C., USA.

Backus, P. 2007. Former FS chiefs say fire costs eating budget. Missoulian (Missoula, Montana, USA). 2007 May 5. [online] URL: http://www.idah oforests.org/fire 20020036.htm.

Berkes, F. 2002. Cross-scale institutional linkages: perspectives from the bottom up. Pages 293-322 in E. Ostrom, T. Dietz, N. Dolsak, P. C. Stern, S. Stovich, and E. U. Weber, editors. The drama of the commons. National Academy Press, Washington, D.C., USA.

Berkes, F. 2004. Rethinking community based conservation. Conservation Biology 18:621-630.

Berkes, F., J. Colding, and C. Folke, editors. 2002. Navigating social-ecological systems: building 
resilience for complexity and change. Cambridge University Press, Cambridge, UK.

Berkes, F., and C. Folke. 1998. Linking social and ecological systems. Cambridge University Press, Cambridge, UK.

Carpenter, S. R., and W. A. Brock. 2008. Adaptive capacity and traps. Ecology and Society 13(2): 40. [online] URL: http://www.ecologyandsociety.org/vol13/ iss $2 / \operatorname{art} 40 /$.

Cash, D. W., W. N. Adger, F. Berkes, P. Garden, L. Lebel, P. Olsson, L. Pritchard, and O. Young. 2006. Scale and cross-scale dynamics: governance and information in a multilevel world. Ecology and Society 11(2):8. [online] URL: http://www.ecology andsociety.org/vol11/iss2/art8/.

Daly, M. 2007. New Forest Service chief gets rough treatment in Congress. Casper Star-Tribune (Casper, Wyoming, USA). 2007 Feb. 14. [online] URL: http://trib.com/news/state-and-regional/ article a69c3158-6d05-57ff-9c67-a156b9056b1e.html

Davis, C. 2006. Western wildfires: a policy change perspective. Review of Policy Research 23:115-127.

Dombeck, M. P., J. E. Williams, and C. A. Wood. 2004. Wildfire policy and public lands: integrating scientific understanding with social concerns across landscapes. Conservation Biology 18:883-889.

FLN. 2003. Crossing boundaries: Workshop 3 of the Fire Learning Network (Little Rock, Arkansas, USA, March 18-21, 2003). The Nature Conservancy, Boulder, Colorado, USA. [online] URL: http://www.tncfire.org/documents/USfln/ USFLN3 summary.pdf.

Folke, C., S. Carpenter, T. Elmqvist, L. Gunderson, C. S. Holling, and B. Walker. 2002. Resilience and sustainable development: building adaptive capacity in a world of transformations. AMBIO 31:437-440.

Forest Landscape Restoration Act of 2008. 2008. S. 2593, 110th Congr. Washington, D.C., USA. [online] URL: http://www.govtrack.us/congress/bill. xpd?bill =s110-2593. [Note: this bill never became law, but its content became part of the Omnibus Public Land Management Act of 2009.]
Goldstein, B. E. 2007. The futility of reason: incommensurable differences between sustainability narratives in the aftermath of the 2003 San Diego cedar fire. Journal of Environmental Policy and Planning 9:227-244.

Goldstein, B. E., and W. H. Butler. 2009. The network imaginary: coherence and creativity within a multiscalar collaborative effort to reform U.S. fire management. Journal of Environmental Planning and Management 52:1013-1033.

Goldstein, B. E., and W. H. Butler. 2010. The U.S. Fire Learning Network: providing a narrative framework for restoring ecosystems, professions, and institutions. Society and Natural Resources 23:935-951.

Gray, B. 1989. Collaborating: finding common ground for multiparty problems. Jossey-Bass Publishers, San Francisco, California, USA.

Gunderson, L., and C. S. Holling. 2002. Panarchy: understanding transformations in human and natural systems. Island Press, Washington, D.C., USA.

Hays, S. P. 1999. Conservation and the gospel of efficiency. University of Pittsburgh Press, Pittsburgh, Pennsylvania, USA.

Healey, P. 1997. Collaborative planning: shaping places in fragmented societies. MacMillan Press, London, England.

Healthy Forests Restoration Act of 2003. 2003. Public Law 108-148, 117 Stat. 1887-1915 (H. R. 1904, 108th Congr.). Washington, D.C., USA. [online] URL: http://www.glin.gov/view.action?gli $\underline{\mathrm{nID}=175679}$.

Holling, C. S., L. H. Gunderson, and D. Ludwig. 2002. In quest of a theory of adaptive change. Pages 3-24 in L. H. Gunderson and C. S. Holling, editors. Panarchy: understanding transformations in systems of humans and nature. Island Press, Washington, D.C., USA.

Innes, J. E., and D. E. Booher. 1999. Consensus building and complex adaptive systems: a framework for evaluating collaborative planning. Journal of the American Planning Association 65:412-423. 
Innes, J. E., S. Connick, and D. E. Booher. 2007. Informality as a planning strategy: collaborative water management in the CALFED Bay-Delta Program. Journal of the American Planning Association 73:195-210.

Kennedy, J. J., and T. M. Quigley. 1998. Evolution of USDA Forest Service organizational culture and adaptation issues in embracing an ecosystem management paradigm. Landscape and Urban Planning 40:113-122.

Kobziar, L. N., M. E. Rocca, C. A. Dicus, C. H. Sugihara, A. E. Thode, J. M. Varner, and P. Morgan. 2009. Challenges to educating the next generation of wildland fire professionals in the United States. Journal of Forestry 107:339-345.

Langston, N. 1995. Forest dreams, forest nightmares: the paradox of old growth in the inland West. University of Washington Press, Seattle, Washington, USA.

Margerum, R., and D. Whitall. 2004. The challenges and implications of collaborative management on a river basin scale. Journal of Environmental Planning and Management 47:409-429.

National Interagency Fire Center. 2010. Fire Information - Wildland Fire Statistics. National Interagency Fire Center, Boise, Idaho, USA. [online] URL: http://www.nifc.gov/fire_info/fire_stats. $\underline{\text { htm. }}$.

Olsson, P., C. Folke, V. Galaz, T. Hahn, and L. Schultz. 2007. Enhancing the fit through adaptive co-management: creating and maintaining bridging functions for matching scales in the Kristianstads Vattenrike Biosphere Reserve, Sweden. Ecology and Society 12:28. [online] URL: http://www.ecolo gyandsociety.org/vol12/iss1/art28/.

Omnibus Public Land Management Act of 2009. 2009. Public Law 111-11, 123 Stat. 991-1456 (H. R. 146, 111th Congr.). Washington, D.C., USA. [online] URL: http://www.glin.gov/view.action?gli $\underline{\mathrm{nID}=86634}$.

Ostrom, E., T. Dietz, N. Dolsak, P. C. Stern, S. Stovich, and E. U. Weber, editors. 2002. The drama of the commons. National Academy Press, Washington D.C., USA.
Pahl-Wostl, C., J. Sendzimir, P. Jeffrey, J. Aerts, G. Berkamp, and K. Cross. 2007. Managing change toward adaptive water management through social learning. Ecology and Society 12:30. [online] URL: http://www.ecologyandsociety.org/vol12/iss2/art30/

Pyne, S. J. 2004. Tending fire: coping withAmerica's wildland fires. Island Press, Washington, D.C., USA.

Pyne, S. J., P. L. Andrews, and R. D. Laven. 1996. Introduction to wildland fire. John Wiley \& Sons, New York, New York, USA.

Repetto, R., and R. B. Allen. 2006. On social traps and lobster traps: choppy waters on the voyage toward fisheries' harvesting rights. Pages 110-136 in R. Repetto, editor. Punctuated equilibrium and the dynamics of US environmental policy. Yale University Press, New Haven, Connecticut, USA.

Schusler, T. M., D. J. Decker, and M. J. Pfeffer. 2003. Social learning for collaborative natural resource management. Society and Natural Resources 15:309-326.

Stake, R. E. 1995. The art of case study research. Sage Publications, Thousand Oaks, California, USA.

Steelman, T. A., and C. A. Burke. 2007. Is wildfire policy sustainable? Journal of Forestry 105:67-72.

The Nature Conservancy. 2010. U.S. Fire Learning Network. The Nature Conservancy, Tallahassee, Florida, USA. [online] URL: http://www.tncfire.org/ training usfln.htm.

USFS. 2005. Revised Land and Resource Management Plan: Ozark-St. Francis National Forests. USDA Forest Service, Washington, D.C., USA.

USFS. 2010. The Forest Service: an overview. USDA Forest Service, Washington, D.C., USA. [online] URL: http://www.fs.fed.us/documents/US FS An Overview 0106MJS.pdf.

USFS and US DOI. 2001. A collaborative approach for reducing wildland fire risks to communities and the environment: 10-year comprehensive strategy. USDA Forest Service and US Department of 
Interior, Washington, D.C., USA. [online] URL:

http://www.westgov.org/wga/initiatives/fire/final_fire_rpt. pdf.

USDA Office of Inspector General. 2006. Audit Report: Forest Service large fire suppression costs. Report No. 08601-44-SF. USDA Office of Inspector General, Washington, D.C., USA. [online] URL: http://www.usda.gov/oig/webdocs/0 8601-44-SF.pdf.

Walker, B., C. S. Holling, S. R. Carpenter, and A. Kinzig. 2004. Resilience, adaptability and transformability in social-ecological systems. Ecology and Society 9:5. [online] URL: http://www. ecologyandsociety.org/vol9/iss2/art5/.

Weber, E. P., and B. Hayward. 2008. Communities can enhance their capacity for socio-ecological resilience to both rapid and gradual climate change. In: The Virginia Tech Symposium on Enhancing Resilience to Catastrophic Events Through Communicative Planning (Blacksburg, Virginia, USA, 2008).

Worster, D. 1994. Nature's economy: a history of ecological ideas. Cambridge University Press, Cambridge, UK.

Yin, R. 2003. Case study research: design and methods. Third edition. Sage Publications, Thousand Oaks, California, USA.

Young, O. R. 2002. Institutional interplay: the environmental consequences of cross-scale interactions. Pages 263-292 in E. Ostrom, T. Dietz, N. Dolsak, P. C. Stern, S. Stovich, and E. U. Weber, editors. The drama of the commons. National Academy Press, Washington, D.C., USA. 